\title{
PENGARUH MODEL PEMBELAJARAN BERBASIS MASALAH TERHADAP HASIL BELAJAR SISWA SMA NEGERI 4 MEDAN T.P. 2014/2015
}

\author{
Andryani Hutabarat*) dan Eva Marlina Ginting**) \\ *) Mahasiswa Jurusan Fisika FMIPA UNIMED \\ **) Dosen Jurusan Fisika FMIPA UNIMED \\ andryani.hutabarat@gmail.com
}

\begin{abstract}
ABSTRAK
Penelitian ini bertujuan untuk mengetahui pengaruh model pembelajaran berbasis masalah pada materi pokok Suhu dan Kalor di kelas X Semester II SMA Negeri 4 Medan T.P. 2014/2015. Jenis penelitian ini adalah quasi eksperimen. Populasi dalam penelitian adalah seluruh siswa kelas X Semester II SMA Negeri 4 Medan yang terdiri dari 11 kelas. Pengambilan sampel dilakukan dengan cara cluster random sampling dengan mengambil 2 kelas dari 11 kelas secara acak yaitu kelas $\mathrm{X}-11$ yang berjumlah 31 siswa sebagai kelas eksperimen dan kelas X-10 yang berjumlah 37 sebagai kelas kontrol. Instrumen yang digunakan untuk mengetahui hasil belajar siswa adalah test hasil belajar dalam bentuk essay tes dengan jumlah 8 soal. Kelas eksperimen diberikan perlakuan dengan penerapan model pembelajaran berbasis masalah dan kelas kontrol dengan model pembelajaran konvensional. Berdasarkan hasil penelitian setelah dilakukan perlakuan menunjukkan bahwa terdapat perbedaan yang signifikan antara hasil belajar siswa dengan menggunakan model pembelajaran berbasis masalah dengan hasil belajar siswa dengan menggunakan pembelajaran konvensional.
\end{abstract}

Kata Kunci : pembelajaran berbasis masalah, hasil belajar, aktifitas

\begin{abstract}
The purpose of the study is to know the effect of the problem based learning model in the subject matter of the Temperature and the Heat on second semester in tenth grade of SMA Negeri 4 Medan. The kind of this study was quasi-experimental. The population of this study was entire tenth grade student on second semester of SMA Negeri 4 Medan which consist of 11 classes. Sample was taking by cluster random sampling method which taking 2 of 11 classes randomly, that were class $X-11$ there are 31 students as experimental class and class $X-10$ there are 37 students as controller class. The instrument which used to know the student's learning outcomes was learning outcomes test in essay which consisted of 8 questions. The experimental class was given the problem based learning model and the controller class was given the conventional learning model. Based on the results of the study after treatment showed that there are significant differences between student learning outcomes by using problem based learning with student learning outcomes by using conventional learning.
\end{abstract}

Keywords: problem based learning, learning outcomes, activities. 


\section{PENDAHULUAN}

Pendidikan merupakan salah satu kebutuhan manusia. Pendidikan tidak dapat diperoleh begitu saja dalam waktu yang singkat, namun memerlukan suatu proses pembelajaran sehingga menimbulkan hasil atau efek yang sesuai dengan proses yang telah dilalui tersebut. Sumber daya manusia yang berpendidikan akan mampu mengikuti perkembangan Ilmu Pengetahuan dan Teknologi (IPTEK). Berbagai usaha dilakukan oleh pemerintah dalam rangka meningkatkan mutu pendidikan di Indonesia salah satunya adalah dengan menetapkan Kurikulum 2013.

Kurikulum 2013 merupakan suatu upaya yang dilakukan oleh pemerintah untuk mewujudkan tujuan dari Pendidikan Nasional di Indonesia yang menekankan kompetensi berbasis sikap, keterampilan dan pengetahuan. Adapun ciri kurikulum 2013 yang paling mendasar ialah menuntut kemampuan guru dalam berpengetahuan dan mencari tahu pengetahuan sebanyak-banyaknya karena siswa zaman sekarang telah mudah mencari informasi dengan bebas melalui perkembangan teknologi dan informasi. Sedangkan untuk siswa lebih didorong untuk memiliki tanggung jawab kepada lingkungan, kemampuan intrapersonal, antarpersonal, maupun memiliki kemampuan berpikir kritis (Imas, 2014).

Upaya pencapaian mutu pendidikan yang lebih baik membutuhkan kerjasama yang baik antar komponen pendidikan sehingga tercipta pendidikan yang berkualitas. Komponen yang sangat memengaruhi proses pendidikan adalah guru. Hal ini memang wajar, sebab guru merupakan ujung tombak yang berhubungan langsung dengan siswa sebagai subjek dan objek belajar. Bagaimanapun bagus dan idealnya kurikulum pendidikan, bagaimanapun lengkapnya sarana dan prasarana pendidikan, tanpa diimbangi dengan kemampuan guru dalam mengimplementasikannya, maka semuanya akan kurang bermakna (Sanjaya, 2011). Kualitas seorang guru dalam mengajar akan mempengaruhi keberhasilan belajar siswa, maka guru harus mampu menciptakan suasana kelas yang kondusif bagi kelangsungan belajar siswa. Salah satunya adalah pemilihan metode pembelajaran yang dapat memancing keinginan siswa untuk belajar termasuk pada bidang IPA, khususnya pelajaran fisika.

Hasil wawancara yang dilakukan pada salah satu guru fisika di SMA Negeri 4 Medan pada tanggal 6 Januari 2015 diketahui bahwa pembelajaran masih menggunakan model pembelajaran konvensional, seperti metode ceramah, diskusi dan tanya jawab. Hasil belajar fisika siswa juga masih rendah yang dibuktikan dengan perolehan nilai siswa kelas $\mathrm{X}$ dalam Ujian Akhir Semester Ganjil pada Tahun Pelajaran 2014/2015 yang masih banyak di bawah Kriteria Ketuntasan Minimal (KKM) yang akan dicapai yaitu 2,67 (B') dan harus melakukan remedial atau ujian ulang. Hal ini relevan dengan data yang diperoleh dari instrumen angket yang disebarkan kepada 30 siswa, diperoleh bahwa $36,67 \%$ siswa menyatakan bahwa fisika sulit dan kurang menarik, 20\% siswa menyatakan bahwa fisika di kelas itu biasa saja, 16,67\% siswa menyatakan fisika mudah dan menyenangkan, dan $26,67 \%$ siswa menyatakan fisika membosankan. 
Berdasarkan kenyataan tersebut, perlu diterapkan suatu model pembelajaran yang sesuai dan mampu meningkatkan aktivitas dan hasil belajar fisika siswa. Salah satu alternatif model pembelajaran yang memungkinkan diterapkan adalah model Pembelajaran Berbasis Masalah (PBM). Model PBM merupakan pendekatan yang efektif untuk pengajaran proses berpikir tingkat tinggi (Trianto, 2011). Pembelajaran PBM dikembangkan untuk membantu siswa mengembangkan kemampuan berpikir, pemecahan masalah dan keterampilan intelektual, belajar berbagai peran orang dewasa melalui perlibatan mereka dalam pengalaman nyata dan menjadi pembelajar yang otonom dan mandiri.

Derek (2005) mengatakan bahwa "Problem Based Learning can be described as an instructional strategy in which student confront conceptually ill-structured problems and strive to find meaningful solutions" yang berarti "Pembelajaran berbasis masalah dapat dideskripsikan sebagai sebuah strategi pembelajaran dimana siswa menghadapi masalah konseptual dan berusaha menemukan solusi bermakna" Dalam PBM siswa didorong untuk memecahkan sebuah masalah yang disusun dalam suatu kerangka pikiran yang nyata (Derek, 2005).

Berdasarkan pemaparan tentang penelitian yang berkaitan dengan penelitian ini, maka dapat dilihat bahwa ada pengaruh yang signifikan antara model PBM terhadap hasil belajar siswa. Pada PBM siswa dituntut untuk melakukan pemecahan masalah-masalah yang disajikan dengan cara menggali informasi sebanyak-banyaknya, kemudian menganalisis dan mencari solusi dari permasalahan yang ada. PBM mengorientasikan siswa kepada masalah, multidisiplin, menuntut kerjasama dalam penelitian, dan menghasilkan karya.

Berdasarkan uraian di atas, maka penulis tertarik untuk melakukan penelitian dengan tujuan untuk mengetahui pengaruh model pembelajaran berbasis masalah terhadap hasil belajar siswa SMA Negeri 4 Medan T.P. 2014/2015".

\section{METODE PENELITIAN}

Penelitian ini dilaksanakan di SMA Negeri 4 Medan dengan populasi seluruh siswa kelas X SMA Negeri 4 Medan yang terdiri dari sebelas kelas. Teknik pengambilan sampel dilakukan dengan cara teknik sampel kelas acak (cluster random sampling). Sampel kelas diambil dari populasi sebanyak dua kelas, yaitu kelas X-11 yang berjumlah 31 orang dengan menggunakan model pembelajaran berbasis masalah dan kelas X-10 yang berjumlah 37 orang dengan menggunakan pembelajaran konvensional. Hasil belajar siswa diperoleh dengan memberikan tes pada kedua kelas sebelum dan sesudah diberi perlakuan. Rancangan penelitian quasi experiment ini dengan two group pretest-postest design. Alat pengumpul data dalam penelitian ini adalah tes hasil belajar berbentuk essay test sebanyak 8 soal. Tes hasil belajar ini digunakan untuk mengetahui kemampuan siswa.

Data tes hasil belajar yang diperoleh diuji normalitasnya untuk mengetahui data kedua sampel berdistribusi normal dengan uji normalitas yaitu digunakan uji Lilliefors. Kemudian dilakukan uji homogenitas untuk mengetahui apakah kedua sampel berasal dari populasi yang homogen digunakan uji 
kesamaan varians. Uji hipotesis digunakan dengan membandingkan rata-rata skor hasil belajar yang dicapai baik kelas eksperimen maupun kelas kontrol. Data yang diperoleh ditabulasikan kemudian dicari rata-ratanya.

Sebelum dilakukan penganalisisan data, terlebih dahulu ditentukan skor masing-masing kelompok sampel lalu dilakukan pengolahan data. Uji $\mathrm{t}$ dua pihak digunakan untuk mengetahui kesamaan kemampuan awal siswa pada kedua kelompok sampel. Uji t satu pihak digunakan untuk mengetahui pengaruh dari suatu perlakuan yaitu model pembelajaran berbasis masalah terhadap hasil belajar siswa.

\section{HASIL DAN PEMBAHASAN Hasil Penelitian}

Di awal penelitian kedua kelas diberikan pre-test (tes kemampuan awal) yang bertujuan untuk mengetahui apakah kemampuan awal siswa kedua kelas sama atau tidak. Hasil pre-test pada kelas eksperimen dan kelas kontrol dalam rentang nilai 0-100. Berdasarkan data hasil penelitian pre-test pada kelas eksperimen diperoleh nilai terendah 17 , nilai tertinggi 57 , nilai rata-rata 37,45 dan standar deviasi 11,81. Pada kelas kontrol diperoleh nilai terendah 13 dan nilai tertinggi 56 dengan nilai rata-rata 37,27 dan standar deviasi 9,24 .

Setelah

dilakukan

pembelajaran, kedua kelas sampel yaitu kelas eksperimen dan kelas kontrol diberikan postes yang bertujuan untuk melihat kemampuan akhir belajar siswa pada kedua kelas tersebut. Setelah diberi perlakuan yang berbeda dimana pada kelas eksperimen diberikan pembelajaran dengan model PBM dan pada kelas kontrol diberikan pembelajaran Konvensional, maka diperoleh data untuk nilai eksperimen dengan nilai terendah 39 , nilai tertinggi 90 , nilai rata-rata 69,94 dan standar deviasi 13,61. Sedangkan pada kelas kontrol diperoleh nilai terendah 40 dan nilai tertinggi 80 dengan nilai rata-rata 64,92 dan standar deviasi 10,65.

Uji normalitas data pretes dan postes kelas eksperimen dan kelas kontrol digunakan untuk mengetahui apakah data pretes dan postes berdustribusi normal. Uji Normalitas dilakukan dengan menggunakan uji Lilliefors.

Berdasarkan hasil uji pada data pretes dengan taraf nyata $=0,05, \mathrm{n}=31$ maka diperoleh $\mathrm{L}_{\text {hitung }}<\mathrm{L}_{\text {tabel }}(0,1193$ $<0,1591$ ) sehingga dapat disimpulkan bahwa data berdistribusi normal pada kelas eksperimen, kemudian pada kelas kontrol diperoleh $\mathrm{L}_{\text {hitung }}<\mathrm{L}_{\text {tabel }}$ $(0,0826<0,1457)$ sehingga dapat disimpulkan bahwa data berdistribusi normal. Pada pengujian normalitas data postes pada kelas eksperimen diperoleh diperoleh $\mathrm{L}_{\text {hitung }}<\mathrm{L}_{\text {tabel }}$ $(0,1452<0,1591)$ sehingga dapat disimpulkan bahwa data berdistribusi normal kemudian pada kelas kontrol diperoleh $\mathrm{L}_{\text {hitung }}<\mathrm{L}_{\text {tabel }}(0,1093<$ 0,1457 ) sehingga dapat disimpulkan bahwa data berdistribusi normal.

Uji homogenitas menggunakan uji $\mathrm{F}$ untuk data pretes menunjukkan bahwa $F_{\text {hitung }}<\mathrm{F}_{\text {tabel }}$ $(1,63<1,78)$, sehingga dapat disimpulkan bahwa data pretes kelas kontrol dan kelas eksperimen homogen. Pada pengujian homogenitas data postes diperoleh $F_{\text {hitung }}<F_{\text {tabel }}(1,63<1,78)$, sehingga dapat disimpulkan bahwa data pretes kelas kontrol dan kelas eksperimen homogen. 
Ada tidaknya perbedaan akibat pengaruh model Pembelajaran Berdasarkan Masalah terhadap hasil belajar siswa pada materi Suhu dan Kalor dapat diketahui dengan melakukan uji beda untuk membandingkan nilai postes kelas eksperimen dengan kelas kontrol, dimana sebelumnya dilakukan pretes pada kedua kelas untuk mengetahui apakah kedua kelas mempunyai kemampuan yang sama sebelum perlakuan. Berdasarkan hasil perbandingan antara $t_{\text {hitung }}$ dan $t_{\text {tabel }}$, maka $-\mathrm{t}_{\text {tabel }}<\mathrm{t}_{\text {hitung }}<\mathrm{t}_{\text {tabel }}$ yaitu $1,998<0,071<1,998$, sehingga dapat diperoleh kesimpulan bahwa antara kelas eksperimen dan kelas kontrol mempunyai kemampuan awal yang sama.

Berdasarkan pengujian data postes dengan uji t satu pihak maka diperoleh $t_{\text {hitung }}>\mathrm{t}_{\text {tabel }}$ yaitu $1,73>$ 1,67 maka $\mathrm{H}_{0}$ ditolak dan $\mathrm{H}_{\mathrm{a}}$ diterima dengan kata lain bahwa rata-rata hasil belajar siswa pada kelas eksperimen lebih tinggi daripada rata-rata hasil belajar siswa pada kelas kontrol, berarti hasil belajar fisika dengan menggunakan model pembelajaran berbasis masalah lebih baik daripada pembelajaran konvensional, sehingga dapat disimpulkan adanya perbedaan hasil belajar yang signifikan akibat pengaruh penerapan model pembelajaran berbasis masalah pada materi Suhu dan Kalor di kelas X Semester 2 SMA Negeri 4 Medan T.P. 2014/2015.

\section{Pembahasan}

Hasil penelitian menunjukkan bahwa ada pengaruh signifikan pada kelas yang menggunakan model pembelajaran berbasis masalah terhadap hasil belajar fisika siswa pada materi pokok Suhu dan Kalor kelas X IPA semester II SMA Negeri
4 Medan T.P 2014/2015. Hal ini diperkuat dengan perolehan nilai ratarata pretes siswa di kelas eksperimen sebesar 37,45 dengan standar deviasi 11,81 dan nilai rata-rata postes sebesar 69,94 dengan standar deviasi 185,33. Sedangkan di kelas kontrol diperoleh nilai rata-rata pretes siswa sebesar 37,27 dengan standar deviasi 9,24 dan nilai rata-rata postes sebesar 64,92 dengan standar deviasi 10,65 dan diperoleh $t_{\text {hitung }}>t_{\text {tabel }}=(1,73>$ 1,67) maka dapat disimpulkan bahwa $\mathrm{H}_{0}$ ditolak dan $\mathrm{H}_{\mathrm{a}}$ diterima.

Pada dasarnya, tujuan utama penelitian ini adalah untuk mengetahui pengaruh model pembelajaran berbasis masalah terhadap hasil belajar siswa. Namun, peneliti juga ingin melihat dan menilai bagaimana aktivitas siswa selama dilaksanakan model pembelajaran berbasis masalah, maka perlu dilakukan pencatatan terhadap aktivitas siswa selama kegiatan pembelajaran berlangsung. Persentase aktivitas siswa tiap pertemuan mengalami peningkatan dari pertemuan I sebesar $62,70 \%$, ke II sebesar 82,95\%, ke III sebesar $82,95 \%$ dan ke IV sebesar $86,35 \%$.

Selama pelaksanaan penelitian diperoleh bahwa model pembelajaran berbasis masalah menguntungkan karena model ini memang didesain untuk mengajak siswa untuk berfikir secara individual dan kelompok untuk memecahkan masalah dalam situasi nyata, membangun pengetahuannya sendiri melalui aktivitas belajar. Model pembelajaran berfokus pada masalah sehingga materi yang tidak ada hubungannya tidak perlu saat itu dipelajari oleh siswa. Hal ini mengurangi beban siswa dengan menghafal atau menyimpan informasi. 
Pada tahap Orientasi siswa pada masalah, peneliti mengajukan suatu permasalahan yang dikaitkan dengan pelajaran untuk dikerjakan oleh siswa secara pribadi, dan siswa berpikir secara mandiri mengenai permasalahan yang diajukan. Pada tahapan ini, siswa berusaha untuk memperoleh jawaban sendiri sesuai dengan kemampuan masing-masing.

Pada tahap Mengorganisasi siswa untuk belajar, siswa duduk berkelompok dengan teman satu kelompok yang telah ditentukan dan menyamakan pemikiran mengenai apa yang telah dibahas pada fase sebelumnya. Interaksi selama tahap ini dapat memadukan jawaban bersama di dalam pasangannya.

Kegiatan pada tahap penyelidikan kelompok, siswa mengumpulkan informasi yang sesuai sampai siswa benar-benar memahami permasalahan yang diberikan dan membangun ide sendiri serta peneliti mengajukan pertanyaan tentang kelayakan solusi yang dibuat serta kualitas informasi yang dikumpulkan.

Kegiatan pada tahap penyajian hasil karya, anggota kelompok berbagi hasil pemikirannya dengan anggota kelompok yang lain atau dengan seluruh kelas. Dengan presentase tersebut, kelompok lainnya dapat membandingkan hasil yang diperolehnya sehingga meningkatkan pemahaman siswa terhadap materi yang sedang dipelajari.

Kegiatan pada tahap menganalisis dan mengevaluasi proses pemecahan masalah, siswa bisa menanyakan bagian mana yang kurang dipahami baik pada kelompok yang presentase atau pun kepada peneliti.

Akan tetapi dalam penelitian ini ditemukan beberapa kendala yang dialami oleh peneliti pada saat menggunakan model pembelajaran berbantuan logis matematis antara lain adalah: (1) situasi yang kurang kondusif pada saat pembelajaran dimana pada tahap mengorganisasikan siswa untuk belajar ada sebagian siswa yang tidak membahas tentang permasalahan yang diberikan justru membahas hal lain di luar permasalahan yang diberikan sehingga siswa tersebut kurang memahami maksud dari masalah yang diberikan. Hal ini mengganggu suasana pembelajaran di kelas karena siswa lain tidak nyaman dalam belajar. Selain itu kendala tersebut sangat berpengaruh pada tahap berikutnya karena pemahaman siswa pada tahap mengorganisasikan siswa untuk belajar mempengaruhi efektivitas pembelajaran pada tahap penyelidikan kelompok.

kurangnya komunikasi antara peneliti dan observer dimana tidak semua siswa yang dipantau oleh observer diketahui keadaannya oleh peneliti, sehingga peneliti tidak melakukan perlakuan tersendiri kepada beberapa siswa untuk meningkatkan hasil belajarnya. Komunikasi antara observer dan peneliti sangat dibutuhkan untuk meningkatkan hasil belajar siswa.

Beberapa kendala yang
dialami oleh peneliti di atas,
diharapkan kepada peneliti selanjutnya agar lebih baik dalam membimbing siswa pada setiap tahap terutama pada tahap mengorganisasikan siswa untuk belajar supaya siswa tidak membicarakan hal lain di luar materi yang dipelajari. Peneliti selajutnya juga diharapkan agar berkomunikasi lebih baik dengan observer sehingga siswa yang dipantau oleh observer diketahui keadaannya oleh peneliti dengan demikian, peneliti dapat 
melakukan perlakuan tersendiri terhadap beberapa siswa untuk meningkatkan hasil belajarnya.

\section{SIMPULAN}

Setelah dilakukan tabulasi, perhitungan dan pengujian hipotesis diperoleh beberapa kesimpulan antara lain: (1) Hasil belajar fisika siswa kelas X IPA semester II SMA Negeri 4 Medan tahun pelajaran 2014/2015 dengan menggunakan model pembelajaran berdasarkan masalah pada materi pokok suhu dan kalor termasuk dalam kategori baik. (2) Hasil belajar fisika siswa kelas X IPA semester II SMA Negeri 4 Medan tahun pelajaran 2014/2015 dengan menggunakan pembelajaran konvensional pada materi suhu dan kalor termasuk dalam kategori cukup baik. (3) Aktivitas belajar siswa selama menggunakan model pembelajaran berdasarkan masalah berbantuan logis matematis mengalami peningkatan yang signifikan, pada pertemuan I $62,70 \%$, pertemuan II $82,95 \%$, pertemuan III $84,92 \%$, dan pada pertemuan IV $86,35 \%$. (4) Berdasarkan hasil pengolahan data dengan analisis pengujian hipoesis menggunakan uji $\mathrm{t}$ dapat dinyatakan bahwa ada perbedaan akibat pengaruh model pembelajaran model pembelajaran berdasarkan masalah terhadap hasil belajar siswa pada materi suhu dan kalor kelas X IPA SMA Negeri 4 Medan T.P. 2014/2015.

\section{SARAN}

Saran yang dapat peneliti ajukan berdasarkan pembahasan (1) Untuk peneliti selanjutnya agar lebih baik dalam membimbing siswa pada setiap tahap terutama pada tahap mengorganisasikan siswa untuk belajar supaya siswa tidak membicarakan hal lain di luar materi yang dipelajari. (2) Peneliti selajutnya juga diharapkan agar berkomunikasi lebih baik dengan observer sehingga siswa yang dipantau oleh observer diketahui keadaannya oleh peneliti.

\section{DAFTAR PUSTAKA}

Derek, (2005), A Short Course In Problem Based Learning $(P B L)$, Mc. Master University, Canada.

Imas, (2014), Sukses Mengimplementasi Kurikulum 2013, Kata Pena, Jakarta.

Sanjaya, W., (2011), Strategi Pembelajaran Berorientasi Standar Proses Pendidikan, Kencana Prenada Media Group, Jakarta.

Trianto, (2011), Mendesain Model Pembelajaran InovatifProgresif, Prestasi Pustaka, Jakarta. 